\title{
Personality Trait as Predictor of Affective Commitment
}

\author{
Umi Anugerah Izzati, Fendy Suhariadi, Cholichul Hadi \\ Faculty of Psychology, Airlangga University, Surabaya, Indonesia \\ Email: umianugerah@gmail.com
}

Received March 2015

\begin{abstract}
This research aims to investigate the influence of personality trait on affective commitment vocational teachers. The population of this survey is vocational teachers in a foundation in the field of education in Surabaya. The technique of collecting data uses questionnaires, while data analysis techniques use regression analysis. The results showed that personality trait had a significant influence on the affective organizational commitment of teachers in Vocational High School. In addition, it was found that two of the five personalities are trait agreeableness and conscientiousness that significantly influenced the affective organizational commitment. It means that teachers who have agreeableness and conscientiousness trait will have emotional attachment, identification and full involvement to organization.
\end{abstract}

\section{Keywords}

Agreeableness, Conscientiousness, Affective Commitment

\section{Introduction}

Education in Indonesia has a wide range of formal education consisting of basic education, secondary education, and higher education, while the type of education includes general education, vocational, academic, professional, vocational, religious, and special. Currently the government is improving the function of secondary vocational schools. Law on the National Education System 20 of 2003 states that the objective is to improve the ability of vocational learners to be able to develop themselves in line with the development of science, technology, art, and prepare students enter the workforce and develop a professional attitude [1]. These objectives can be interpreted that the Vocational High School graduates are expected to have the readiness to enter the workforce.

In order to achieve these objectives required by the role of teachers in each secondary vocational school, the teacher's role in producing quality graduates is an important component that must be continuously observed. Teachers are required to act in a professional manner. Professionalism and quality of work of teachers is an indicator of the commitment of teachers to the school as an organization where she taught. Therefore it can be said that, a teacher who has a commitment to strive to work in earnest to achieve school goals wholeheartedly for the school progress (Hutapea, 2012) [2].

Several studies have been conducted several experts produce findings that there are negative impacts that 
would arise when the human resources within an organization does not have a commitment to the organization for which they work. Research Wong (2002) [3] showed that there was significant negative effect relationship between affective commitment with turnover intention. This suggests that employees who have a high affective commitment, the organization will lower turnover intention. While research conducted Luchak and Gellatly (2007) [4] found some results such that affective commitment is negatively related to turnover and absenteeism while affective commitment has a positive relationship with performance. Based on several studies that have been conducted by experts it can be concluded that affective commitment has an important role for an organization to achieve its objectives. As well as research conducted Barnes, Crowe, and Schaefer (2007) [5] which estimates the amount of losses incurred on a few school districts in the United States are caused by out-inclusion of teachers from one school to another school or teacher cessation of his job as a teacher. This further reinforces the belief that the teaching profession requires a lot of thought as well as the outpouring of heartfelt needed in daily life. Teaching is not just present the facts but also dedication his whole heart and time (Day, 2004 in Hutapea (2012)) [2] [6]. The studies above bring the needed attention to the issue of teachers' organizational commitment to the school.

Research on organizational commitment is generally performed in the background of the hospital, business and banking organizations and is rarely found in the context of education or educational institutions, especially in Surabaya Indonesia. Research on organizational commitment in educational institutions in Indonesia, as far as can be found in scientific publications, recently conducted by several researchers such as Seniati research (2006) [7] on the lecturer civil servants remain active and have worked for at least one year at the University of Indonesia concluded that the period of employment, agreeabelness trait, and job satisfaction has a direct influence on organizational commitment, while the psychological climate of an indirect effect through job satisfaction. While research Hutapea (2012) [2] on the male teachers in primary schools concluded that personality trait and perceptions of organizational support had an influence on organizational commitment. Based on several studies that have been done, it can be interpreted that the research on the organizational commitment of educators and antesendennya needs to be done to support the school in achieving its objectives.

Important organizational commitment is owned by each individual in an organization. Organizational commitment is a condition in which the individual in favor of the organization's goals and wishes to maintain keangotaannya in the organization (Robbins and Judge, 2007) [8]. While Allen and Meyer (1990) [9] and (1991) [10] and Meyer, et al. (2002) [11], states that organizational commitment has three approaches are called components of organizational commitment. The components consist of affective commitment, continuous commitment and normative commitment. The development of the research literature on the third commitment, it was found that that has the most dominant element in shaping the organization's commitment is affective commitment. This is shown by research conducted by Meyer, et al. (2002) [11] on the meta-analysis and its organizational commitment anteseden which affective commitment has the highest rate compared with two other commitments._Individuals who have a strong affective commitment will continue its work in the organization as agreed with the objectives of the organization and the desire to do so (want to do so). Therefore, this study focuses on affective commitment to the organization, because researchers assume that affective commitment has an important role in an organization.

Affective commitment refer to emotional attachment, identification and involvement of individuals to organization. Allen and Meyer (1990) [9] and (1991) [10]. It means individu will be able to develop emotional attachment to the organization at time they were able to identify with the goals of the organization and have a willingness to assist the organization in achieving the objectives. Identification with the goals of the organization occurs if the values of the individual in accordance with the values of the organization where he works so that the individual is able to internalize the values and goals of the organization. Individuals will be settled in the organization because it has its own desires.

Knowledge of the researcher, the research on affective commitment has never been done in Surabaya, so it makes researchers interested in studying the affective commitment of teachers in private vocational high school in Surabaya. Researchers interested in conducting research on teachers working in private schools because when viewed from the side and the revenue earned facility is different than the teachers who work in public schools. Total income and welfare benefits gained teachers working in private schools is much lower than the teachers who work in public schools.

Allen and Meyer (1997) [12] suggested that the antecedents of affective organizational commitment one of which is a dispositional variables consisting of values and personality. While research studies Mowday, Porter 
and Steers (1982) [13], the antecedents of organizational commitment includes: a) personal characteristics consisting of age, length of employment, gender, and level of education, personality, b) structural characteristics, c) characteristics related to the job or position that consists of the challenges of work, the dual role conflict and role ambiguity; and d) work experience, include leadership styles, organizational reliability, and colleagues provide an influence on organizational commitment. While Meyer, et al. (2002) [11], suggests there are several categories, namely, demographic variables, individual differences and work experience are the antecedents of affective organizational commitment. The existence of several antecedents that influence the affective commitment of the organization, the researcher focuses on one of the dispositional variables that personality trait. Selection of personality traits in this study by researchers interesting to study.

Literature study conducted by researchers on the influence of personality trait on organizational commitment, especially affective organizational commitment includes research that is rarely done. Therefore, research Seniati (2006) [7] and Hutapea (2012) [2] became the basis for this study. In both these studies it can be concluded that personality traits influence more stable and survive on organizational commitment as a personality trait is something that is inherent in an individual. As for the difference of this study by the research above is the second of the above research focuses on overall organizational commitment, while this study focuses on affective organizational commitment. One of the antecedent variables that affect the formation of affective commitment is the personality that this study to look at the influence of personality traits on affective commitment.

Personality by nature can be seen, among others, by using the big five personality (the big five personality) Big five personality taxonomy is a comprehensive assessment of personality in which individuals perceive how himself and how his relationship with others. Assessment in five major personality not produce one single dominant trait, but it shows how strong each trait in a person Seniati (2006) [7]. Goldberg (1992) [14] suggested that the five dimensions are: a) Extraversion, characterized by the presence of spirit and enthusiasm. Individuals ekstraver excited in building relationships with other people. Individuals described as enthusiastic. This enthusiasm is reflected in the emission of positive emotions. Individuals can be firm and assertive in attitude. b) Agreeableness, discrete sincerity in sharing, sensitivity, focus on the positive things in others. Everyday they come across as kind-hearted individual, can cooperate and trustworthy. c) Conscientiousness, can be interpreted in earnest in doing tasks, responsible, reliable, and fond of order and discipline. In everyday life they appear as a timely attendance, achievement, meticulous, and like to do the job thoroughly. d) Neuroticism is synonymous with the presence of negative emotions such as anxiety, tension, and fear. Individuals who have a dominant trait is easily nervous in the face of problems that according to the most just trivial. They easily become angry when confronted with a situation that is not in accordance with what he wanted. e) Openness or openness to experience, can be interpreted as openness insight and originality. They are open ready to receive a variety of stimuli that exist with open angles because their insights not only widespread but also deep. Descriptions of the big five personality traits above, the researchers suspect that there are significant between the personality trait affective organizational commitment to the teacher.

Based on the above, the researchers propose the following hypothesis: Personality trait consisting of agreeableness, conscientiousness, extraversion, openness to experience and neurotic influence affective commitment.

\section{Method}

\subsection{Participants}

Participants in this study amounted to 105 persons Vocational High School teacher who works in a educational foundation Surabaya Indonesia with minimal education characteristics S1.

\subsection{Research Design}

This study uses a quantitative approach, where researchers conducted a survey into the field to collect data to the participants.

\subsection{Research Tools}

Researchers used two types of questionnaires, namely a personality trait questionnaires The Big Five Personality Inventory Test by Goldberg (John \& Srivastava, 1999) [15] which has been adapted by Ramdhani (2012) [16]. The 44-item BFI uses short phrases to describe the trait adjectives which form the personality. Measuring affec- 
tive organizational commitment of Allen and Meyer (1990) [9] researchers modified in accordance with the conditions that the teacher participants. Each statement in the questionnaire there are seven choices of alternative answers. The method of measurement is self rating, where respondents provide feedback by choosing one alternative answers among the answers.

\subsection{Data Analysis Techniques}

Statistical calculations were used to test the research hypothesis is multiple regression analysis (multiple regression analysis) using SPSS 20.00.

\subsection{Research Procedure}

This study uses a field of research that is distributing questionnaires directly to the teachers of vocational schools in accordance with predetermined characteristics. Before distributing questionnaires, the researchers requested permission to the head where he did research education foundation. The process of data collection was conducted during 10 working days. This is because the teachers are working on the questionnaire during school recess. The number of questionnaires distributed 115 questionnaires exist but after returning questionnaires returned by the researchers examined the number of questionnaires that could be analyzed there were 105 questionnaires.

\section{Results}

The number of participants are 105 with categories male participants by $42.9 \%$ (45 people) and the women $57.1 \%$ (60 people). Based on the level of education, $94.3 \%$ (99 people) of participants had S1, while as much as 5.7\% (6 people) have education S2.

Based on the results of the regression analysis in Table 1 can be seen that there is a significant effect of $87.4 \%$ between the personality trait of the affective commitment.

As each of these factors result that agreeableness give t value of 5.489 (positive) with a significance value of 0.000 is smaller than the significance level $\alpha=0.05$ was used. This suggests that the agreeableness factor has an influence on affective commitment. It can be concluded that there is a significant relationship between Agreeablenes with affective commitment. While conscientiousness give t value of 5.442 (positive) with a significance value of 0.000 is smaller than the significance level $\alpha=0.05$ was used. This shows that conscientiousness has a significant influence on affective commitment. Extraversion t value of 1.080 (negative) with a significance value of 0.283 is greater than the significance level $\alpha=0.05$ was used. This shows that Extraversion not have a significant effect on affective commitment. Thus it can be said that there was no significant effect on affective commitment. Openess can be seen $t$ value of -1.924 (negative) with a significance value of 0.059 is greater than the significance level $\alpha=0.05$ was used. This suggests that the Openess not have a significant effect on affective commitment. Neurotism can be seen t value of 0.879 (negative) with a significance value of 0.381 is greater than

Tabel 1. Table regression analysis.

\begin{tabular}{lccc}
\hline \multicolumn{1}{c}{ Trait Personality } & $\beta$ & $\mathrm{t}$ & Sig. \\
\hline Agreeableness & 0.560 & 5.489 & 0.000 \\
Conscientiousness & 0.395 & 5.442 & 0.000 \\
Extraversion & 0.094 & 1.080 & 0.283 \\
Openness to experience & -0.173 & -1.924 & 0.059 \\
Neuroticism & 0.071 & 0.879 & 0.381 \\
Multiple R & 54.197 & & \\
$\mathrm{R}^{2}$ & 0.874 & & \\
$\mathrm{~F}$ & 137,391 & & \\
Signifikansi & 0.000 & & \\
\hline
\end{tabular}


the significance level $\alpha=0.05$ was used. This suggests that Neurotism not have a significant effect on affective commitment. Thus, in this study of the entire personality trait of five personality, only two personalities that show a significant effect on affective commitment.

\section{Discussion}

In this study, we can conclude that the personality trait that has a significant influence on the affective organizational commitment is agreeableness and conscientiousness. Agreeableness trait that can be called also social adaptibility that indicate someone who is friendly, cooperative, tender-hearted, generous, warm, trusting of others, refused to budge, tolerance, and avoid conflicts. This research support result of research by Lee, et al. (2001) [17]. They research showed that agreeableness were significantly correlated with affective commitment. Regression analyses showed that agreeableness as predictors of affective commitment organization. So, it can show that teacher who have high agreeableness have emotional attachment and identification to the school where they worked.

While conscientiousness described as nature earnest, responsible, diligent, organized, punctual, willing to work hard and success oriented. Therefore, a teacher who has the properties will have a sense of conscientiousness so willing to involvement how to work hard with all their abilities for the betterment of the school because they have responsibility, diligent, organized, punctual, willing to work hard. This research also support research by Erdheim, et al., (2006) [18]; Matzler \& Renzl, (2007) [19] they found that the positive correlation between conscientiousness and affective commitment.

Finding of this study is the role of conscientiousness that influence the affective commitment of teachers to school, especially for vocational education teachers. This is a complement of the few studies on the influence of personality traits on affective commitment, which previously has not been investigated conscientiousness factor influence on affective commitment to the organization of educators, teachers and lecturers in Indonesia.

This study contains a number of limitations that should be considered. First, the study was only performed on two vocational high schools that are from at the same foundation that emphasizes the religious values with a small number compared to the number of teachers of vocational high schools in Surabaya. Therefore, the results of this study can not be generalized widely but is limited to teachers of vocational high school who became participants of this study. Second, this research has not considered the demographic variables such age, period of employment and marital status can affect affective organizational commitment (Meyer, et al, 2002) [11], it is given that these factors are very unbalanced comparison participants in particular tenure, age and marital status. Therefore, these findings allow further research to consider a number of demographic factors.

This study can be considered as a preliminary study and could continue for the development of research because research on affective commitment to the organization of vocational high school teacher's knowledge has not been much research done in Indonesia. Although this study has some limitations but this research has contributed to the understanding and explanation of affective organizational commitment vocational high school teachers, especially in terms of the personality trait, especially in the fields of organizational behavior and psychology are expected to be useful theoretically and practically.

The findings of this study indicate that 1) Personality trait as predictors of affective organizational commitment of teachers in vocational schools. 2) Agreeableness and conscientiousness trait contribute significantly to the affective organizational commitment.

Based on the results of research and discussion above may be considered suggestions as follows: 1) For other researchers who are interested in the same problems, are expected to conduct research involving a larger number of participants with sampling techniques are more numerous using techniques such as random cluster sampling or sensus; 2) In addition, it is also advisable to involve demographic factors mentioned above; 3) This research can proceed with the design of the study and analysis of different techniques such path analysis more comprehensive.

\section{References}

[1] Undang-Undang No. 14 Tahun (2005) Guru dan Dosen.

[2] Hutapea (2012) Sifat-Sifat Kepribadian dan Dukungan Organisasi Sebagai Prediktor Komitmen Organisasi Guru Pria di Sekolah Dasar. Jurnal Makara, Sosial Humaniora, 16, 101-115.

[3] Wong,Y.-T., Ngo, H.-Y. and Wong, C.-S. (2002) Affective Organizational Commitment of Workers in Chinese Joint 
Ventures. Journal of Managerial Psychology, 17, 7-8. http://dx.doi.org/10.1108/02683940210444049

[4] Luchak, A.A. and Gellatly, I.R. (2007) A Comparison of Linear and Nonlinear Relations between Organizational Commitment and Work Outcomes. Journal of Applied Psychology, 92, 786-793. http://dx.doi.org/10.1037/0021-9010.92.3.786

[5] Barnes, G., Crowe, E. and Schaefer, B. (2007) The Cost of Teacher Turnover in Five School Districts: A Pilot Study. Diakses Dari. http://nctaf.org/wp-content/uploads/2012/01/NCTAF-Cost-of-Teacher-Turnover-2007-fullreport.pdf

[6] Day, C. (2004) A Passion for Teaching. Routledge Falmer, London. http://dx.doi.org/10.4324/9780203464342

[7] Seniati, A.N.L. (2006) Pengaruh masa kerja, trait kepribadian, kepuasan kerja dan iklim psikologis terhadap komitmen dosen pada universitas Indonesia. Jurnal Makara, Sosial Humaniora, 10, 88-97.

[8] Robbins and Judge (2007) Perilaku Organisasi. Edisi Kesepuluh. Molan, Benyamin (penerjemah). Prenhallindo, Jakarta.

[9] Allen, N.J. and Meyer, J.P. (1990) The Measurement dan Antecedents of Affective, Continuance, and Normative Commitment. Journal of Occupational Psychology, 63, 1-18. http://dx.doi.org/10.1111/j.2044-8325.1990.tb00506.x

[10] Allen, N.J. and Meyer, J.P. (1991) A Three-Component Conceptualization of Organizational Commitment. Human Resource Management Review, 1, 61-89. http://dx.doi.org/10.1016/1053-4822(91)90011-Z

[11] Meyer, et al. (2002) Affective, Countinuance, and Normative Cpmmitment to the Organization: A Meta-Analysis of Antecedents, Correlates, and Consequences. Journal of Vocational Behavioral, 61, 20-52. http://dx.doi.org/10.1006/jvbe.2001.1842

[12] Meyer, J.P. and Allen (1997) Commitment in the Workplace: Theory, Research and Application. Sage Publication, USA.

[13] Mowday, R.T., Porter, L.W. and Steers, R.M. (1982) Employee-Organization Linkages: The Psychology of Commitment, Absenteeism, and Turnover. Academic Press, New York.

[14] Goldberg, L.R. (1992) The Development of Markers for the Big-Five Factor Structure. Psychological Assessment, 4, 26-42. http://dx.doi.org/10.1037/1040-3590.4.1.26

[15] John and Srivastava (1999) The Big-Five Trait Taxonomy: History, Measurement, and Theoretical Peispectives. Handbook of Personality: Theory and Research. 2nd Edition, Guilford, New York (in Press).

[16] Ramdhani, N. (2012) Adaptasi Bahasa dan Budaya Inventori Big Five. Jurnal Psikologi, 39, 189-207.

[17] Lee, K., Allen, N.J., Meyer, J.P. and Rhee, K.-Y. (2001) The Three-Component Model of Organizational Commitment: An Application to South Korea. Applied Psychology: An International Review, 50, 596-614. http://dx.doi.org/10.1111/1464-0597.00075

[18] Erdheim, J., Wang, M. and dan Zickar, M.J. (2006) Linking the Big Five Personality Constructs to Organizational Commitment. Personality and Individual Differences, 41, 959-970. http://dx.doi.org/10.1016/j.paid.2006.04.005

[19] Matzler, K. and Renzl, B. (2007) Personality Traits, Employee Satisfaction and Affective Commitment. Total Quality Management, 18, 589-598. http://dx.doi.org/10.1080/14783360601061528 